www.jmscr.igmpublication.org

Impact Factor (SJIF): 6.379

Index Copernicus Value: 71.58

ISSN (e)-2347-176x ISSN (p) 2455-0450

crossref DOI: https://dx.doi.org/10.18535/jmscr/v6i5.174

Journal Of Medical Science And Clinical Research

\title{
Estimation of Psychiatric Co-Morbidities in Patients of Tuberculosis Attending- A Tertiary Medical Centre
}

\author{
Authors \\ Dr Mukesh Tiwari, Dr Santosh Kumar, Dr Gajendra Vikram Singh, Dr Vishal Sinha \\ S.N.M.C. Agra (U.P.), India
}

\begin{abstract}
Aims and Objectives: To estimate and compare psychiatric co-morbidities in patients of Tuberculosis depending on duration, category of treatment and various other socio-demographic parameters.

Methodology: 240 patients of tuberculosis, between 18 to 60 years of age were taken into periodic study between April 2015 and March 2016, for evaluation of associated psychiatric co-morbidities at 10-15days and 55-60days after the registration under RNTCP DOTS. We collected information regarding psychiatric symptoms using M.I.N.I. (Mini International Neuropsychiatric interview).

Result: Male to female ratio was 1.3:1, the mean age group was 32.93 years, and majority (70\%) of the patients belonged to lower socioeconomic group. Psychiatric co-morbidities evaluation in patient of tuberculosis on the study group at 10-15 days, patient taking category I treatment 59(24.58\%). Among these 10(16.94\%) had Major depressive episode, 8(13.55\%) had Generalized anxiety disorder, 4(6.77\%) had Obsessive-compulsive disorder, 2(3.38\%) had Manic episode,4(6.77\%) had Social phobia, 4(6.77\%) had Alcohol dependence, 1(1.69\%) had suicidal tendency, 4(6.77\%) had Panic episode and 22(37.2\%) had no psychiatric co-morbidities. As compared to category I, other categories were significantly and independently at high risk of psychiatric co-morbidities. Category II group had $75.47 \%$ and category IV group had $84 \%$ of psychiatric co-morbidities.

Conclusion: Depressive disorder is the most common psychiatric co-morbidity in patients of tuberculosis and more severe in category IV patient, at 10-15days after registration and majority of the patient belong to lower socioeconomic group.
\end{abstract}

\section{Introduction}

Tuberculosis (TB) is an infectious disease caused by the bacillus Mycobacterium tuberculosis. It typically affects the lungs (pulmonary Tuberculosis) but can affect other sites as well (extra-pulmonary Tuberculosis). Overall, a relatively small proportion of people infected with Mycobacterium tuberculosis will develop Tuberculosis. Tuberculosis is a global health problem, particularly in developing countries.
World health organization estimates that 2 billion people have latent Tuberculosis, while another 3 million people worldwide die each year due to Tuberculosis ${ }^{1}$. India has featured among the 22 high Tuberculosis burden countries and has accounted for an estimated one quarter $(26 \%)$ of all Tuberculosis cases worldwide $^{2}$. Studies have shown that the prevalence of depression and other psychiatric disorders is high among patients with Tuberculosis ${ }^{3,4}$. Depression 
is a common mental illness and one of the leading causes of disease burden affecting 121 million people worldwide. Suicide due to depression is associated with the loss of about 850,000 lives every year ${ }^{5}$.studies report high prevalence rates of psychiatric comorbidity among patients with drug-resistant tuberculosis ${ }^{6}$ and that prevalence of depression significantly correlates with severity and duration of the disease. ${ }^{7,8}$

\section{Material and Method}

We will conduct an observational prospective periodic study in which we will collect information regarding associated psychiatric comorbidities at 10-15 days and 55-60 days after the registration under RNTCP DOTS.

Criteria for Inclusion

- All patients registered under RNTCP taking DOTS for tuberculosis at Department of Tuberculosis and Chest diseases, S. N. Medical College, Agra from April 2015 to March 2016.

- Age of patients to be between 18 to 60 years.

- Patients who are able to give informed consent.

Criteria for Exclusion

- All patients registered under RNTCP taking DOTS for tuberculosis at Department of TB and Chest diseases, S. N. Medical College, Agra before April 2015 and after March 2016.

- Patients who are not able to give informed consent.

- Patients with previous history of psychiatric illness were also excluded from the study.

- Patients not in a physical or mental state in which they can comprehend the questions asked or who are not capable of giving a valid response.

- Any patient with co-morbidities which affects occurrence or severity of tuberculosis.

We will collect information by RNTCP DOTS Register, regarding category of treatment such as category-I, category-II, and category-IV. 240 patients were selected by simple random sampling method from outpatient department (OPD), attending at Department of Tuberculosis \& Chest Diseases, S.N. Medical College, Agra. A structured questionnaire was used to collect data on socio-demographic variables such as age, sex, residence and marital status. We will collect information regarding psychiatric symptoms by using Pre-designed semi-structural questionnaire using Mini International Neuropsychiatric Interview $^{9,10}$ (MINI) 10-15 days and 55-60days after the registration under RNTCP DOTS.

\begin{tabular}{|c|c|}
\hline \multicolumn{2}{|c|}{$\begin{array}{l}\text { Table-1 Association of socio-demograph } \\
\text { factors, category of treatment with psychiatric ce } \\
\text { morbidity (At 10-15 days) }\end{array}$} \\
\hline Variables & psychiatric co-morbidity (\%) \\
\hline \multicolumn{2}{|l|}{ AGE(years) } \\
\hline $18-30(n=123)$ & $87(70.73)$ \\
\hline $31-45(n=74)$ & $61(82.43)$ \\
\hline $46-60(n=43)$ & $33(75.42)$ \\
\hline \multicolumn{2}{|l|}{ SEX } \\
\hline $\operatorname{Male}(\mathrm{n}=134)$ & 104(77.61) \\
\hline Female $(n=106)$ & $77(72.64)$ \\
\hline \multicolumn{2}{|l|}{ RESIDENCE } \\
\hline $\operatorname{Rural}(\mathrm{n}=82)$ & $52(63.41)$ \\
\hline $\operatorname{Urban}(\mathrm{n}=158)$ & $128(81.65)$ \\
\hline \multicolumn{2}{|c|}{ SOCIO-ECONOMIC STATUS } \\
\hline $\mathrm{III}(\mathrm{n}=72)$ & $51(70.83)$ \\
\hline $\operatorname{IV}(\mathrm{n}=110)$ & $83(75.45)$ \\
\hline $\mathrm{V}(\mathrm{n}=58)$ & $47(81.03)$ \\
\hline \multicolumn{2}{|l|}{ MARRITAL STATUS } \\
\hline Married(n=164) & $128(81.65)$ \\
\hline Single $(n=76)$ & $53(63.41)$ \\
\hline \multicolumn{2}{|c|}{ CATEGORY OF TREATMENT } \\
\hline Category I(n=59) & $37(62.71)$ \\
\hline Category II(n=106) & $80(75.47)$ \\
\hline Category IV $(n=75)$ & $64(85.33)$ \\
\hline
\end{tabular}

The response rate of this study at both points (1015 days and 55-60day) was $100 \%$, except for those who were not fallow up at DOTS centre. Considering those who were not fallow up at DOTS centre the response rate of this study at end point (55-60day) was $90.41 \%(217)$.

\section{Results}

In present study majority of tuberculosis patients $123(51.25 \%)$ were $18-30$ years age groups, 134 were male, 158 were urban, 110 patients were SES-IV, 164 were married, 106 patients were taking treatment of category II. psychiatric comorbidities were more in 31-45 years age i.e. 
$82.43 \%$, male i.e. $77.61 \%$, urban residence i.e. $81.65 \%$, SES-V i.e. $81.03 \%$, married i.e. 81.65 and in category IV i.e. $85.33 \%$.(TABLE-1)

Prevalence of Psychiatric co-morbidity has been found to be higher in category IV patients as compared to category I and II patients and Major depressive episode is the most common psychiatric co-morbidity among all category of treatment. Prevalence of psychiatric co-morbidity significantly decreases at 55-60days as compare to 10-15days.(Table-2)

Table-2: Mini International Neuropsychiatric Interview AT 10-15 days and 55-60 days

\begin{tabular}{|c|c|c|c|c|c|c|c|c|}
\hline \multirow[t]{3}{*}{ Psychiatric Co-Morbidity } & \multicolumn{3}{|c|}{$\begin{array}{l}\text { Category of treatment(10-15days) } \\
\qquad(n=240)\end{array}$} & \multirow[t]{2}{*}{ Total } & \multicolumn{3}{|c|}{$\begin{array}{c}\text { Category of treatment }(55- \\
\text { 60day })(n=217)\end{array}$} & \multirow[t]{2}{*}{ Total } \\
\hline & I & II & IV & & $\mathbf{I}$ & II & IV & \\
\hline & $\begin{array}{l}\text { No. } \\
(\%)\end{array}$ & $\begin{array}{l}\text { No. } \\
(\%)\end{array}$ & $\begin{array}{l}\text { No. } \\
(\%)\end{array}$ & $\begin{array}{l}\text { No. } \\
(\%)\end{array}$ & $\begin{array}{l}\text { No. } \\
(\%)\end{array}$ & $\begin{array}{l}\text { No. } \\
(\%)\end{array}$ & $\begin{array}{l}\text { No. } \\
(\%)\end{array}$ & $\begin{array}{l}\text { No. } \\
(\%)\end{array}$ \\
\hline Alcohol Dependence & $\begin{array}{c}4 \\
(6.78) \\
\end{array}$ & $\begin{array}{c}8 \\
(7.55) \\
\end{array}$ & $\begin{array}{c}2 \\
(2.67) \\
\end{array}$ & $\begin{array}{c}14 \\
(5.83)\end{array}$ & $\begin{array}{c}3 \\
(5.08)\end{array}$ & $\begin{array}{c}4 \\
(4.35)\end{array}$ & $\begin{array}{c}2 \\
(3.03)\end{array}$ & $\begin{array}{c}9 \\
(4.15)\end{array}$ \\
\hline $\begin{array}{ll}\text { Generalized } & \text { Anxiety } \\
\text { Disorder } & \end{array}$ & $\begin{array}{c}8 \\
(13.56)\end{array}$ & $\begin{array}{c}16 \\
(15.09)\end{array}$ & $\begin{array}{c}10 \\
(13.33)\end{array}$ & $\begin{array}{c}34 \\
(14.17)\end{array}$ & $\begin{array}{c}7 \\
(11.86)\end{array}$ & $\begin{array}{c}12 \\
(13.04)\end{array}$ & $\begin{array}{c}9 \\
(13.64)\end{array}$ & $\begin{array}{c}28 \\
(12.90)\end{array}$ \\
\hline Major Depressive Episode & $\begin{array}{c}10 \\
(16.95)\end{array}$ & $\begin{array}{c}26 \\
(24.53)\end{array}$ & $\begin{array}{c}19 \\
(25.33)\end{array}$ & $\begin{array}{c}55 \\
(22.92)\end{array}$ & $\begin{array}{c}7 \\
(11.86)\end{array}$ & $\begin{array}{c}18 \\
(19.57)\end{array}$ & $\begin{array}{c}14 \\
(21.21)\end{array}$ & $\begin{array}{c}39 \\
(17.97)\end{array}$ \\
\hline Manic Episode & $\begin{array}{c}2 \\
(3.39)\end{array}$ & $\begin{array}{c}6 \\
(5.66) \\
\end{array}$ & $\begin{array}{c}6 \\
(8) \\
\end{array}$ & $\begin{array}{c}14 \\
(5.83) \\
\end{array}$ & $\begin{array}{c}1 \\
(1.69) \\
\end{array}$ & $\begin{array}{c}4 \\
(4.35)\end{array}$ & $\begin{array}{c}5 \\
(7.58)\end{array}$ & $\begin{array}{c}10 \\
(4.61) \\
\end{array}$ \\
\hline $\begin{array}{l}\text { Obsessive-Compulsive } \\
\text { Disorder }\end{array}$ & $\begin{array}{c}4 \\
(6.78)\end{array}$ & $\begin{array}{c}8 \\
(7.55)\end{array}$ & $\begin{array}{c}8 \\
(10.67)\end{array}$ & $\begin{array}{c}20 \\
(8.33)\end{array}$ & $\begin{array}{c}4 \\
(6.78)\end{array}$ & $\begin{array}{c}7 \\
(7.61)\end{array}$ & $\begin{array}{c}7 \\
(10.61)\end{array}$ & $\begin{array}{c}18 \\
(8.29)\end{array}$ \\
\hline Panic Disorder & $\begin{array}{c}4 \\
(6.78)\end{array}$ & $\begin{array}{c}6 \\
(5.66)\end{array}$ & $\begin{array}{c}7 \\
(9.33)\end{array}$ & $\begin{array}{c}17 \\
(7.08)\end{array}$ & $\begin{array}{c}3 \\
(5.08)\end{array}$ & $\begin{array}{c}4 \\
(4.35)\end{array}$ & $\begin{array}{c}5 \\
(7.58)\end{array}$ & $\begin{array}{c}12 \\
(5.53)\end{array}$ \\
\hline Social Phobia & $\begin{array}{c}4 \\
(6.78)\end{array}$ & $\begin{array}{c}8 \\
(7.55)\end{array}$ & $\begin{array}{c}8 \\
(10.67)\end{array}$ & $\begin{array}{c}20 \\
(8.33)\end{array}$ & $\begin{array}{c}4 \\
(6.78)\end{array}$ & $\begin{array}{c}5 \\
(5.43)\end{array}$ & $\begin{array}{c}6 \\
(9.09)\end{array}$ & $\begin{array}{c}15 \\
(6.91)\end{array}$ \\
\hline Suicidality & $\begin{array}{c}1 \\
(1.69)\end{array}$ & $\begin{array}{c}2 \\
(1.89)\end{array}$ & $\begin{array}{c}4 \\
(5.33)\end{array}$ & $\begin{array}{c}7 \\
(2.92)\end{array}$ & $\begin{array}{c}0 \\
(0.00)\end{array}$ & $\begin{array}{c}0 \\
(0.00)\end{array}$ & $\begin{array}{c}0 \\
(0.00)\end{array}$ & $\begin{array}{c}0 \\
(0.00)\end{array}$ \\
\hline $\begin{array}{l}\text { No Psychiatric } \text { Co- } \\
\text { Morbidity }\end{array}$ & $\begin{array}{c}22 \\
(37.29)\end{array}$ & $\begin{array}{c}26 \\
(24.53)\end{array}$ & $\begin{array}{c}11 \\
(14.67)\end{array}$ & $\begin{array}{c}59 \\
(24.58) \\
\end{array}$ & $\begin{array}{c}30 \\
(50.85)\end{array}$ & $\begin{array}{c}38 \\
(41.30)\end{array}$ & $\begin{array}{c}18 \\
(27.27)\end{array}$ & $\begin{array}{c}86 \\
(39.63)\end{array}$ \\
\hline & $\begin{array}{c}59 \\
(100)\end{array}$ & $\begin{array}{c}106 \\
(100)\end{array}$ & $\begin{array}{c}75 \\
(100)\end{array}$ & $\begin{array}{c}240 \\
(100)\end{array}$ & $\begin{array}{c}59 \\
(100)\end{array}$ & $\begin{array}{c}92 \\
(100)\end{array}$ & $\begin{array}{c}66 \\
(100)\end{array}$ & $\begin{array}{c}217 \\
(100)\end{array}$ \\
\hline
\end{tabular}

\section{Discussion}

The psychological aspects of tuberculosis have always been a topic of interest over the centuries. Our study shows the prevalence of psychiatric comorbidity in patients of tuberculosis. The prevalence of psychiatric co-morbidity in patients of tuberculosis could be due to the various psychosocial stresses faced by the patient like social stigma attached to the illness, set back in occupation, social isolation with damaged status, lowered self-esteem, fear of spreading the illness to others and helplessness brought about by incapacitation due to chronic illness. Several studies have attempted to estimate the prevalence of psychiatric co-morbidity in patient of tuberculosis. One study ${ }^{11}$ evaluating psychiatric profile, personality trait of 214 Tuberculosis patients registered on directly observed treatment- short course (DOTS) and evaluated their impact on treatment completion and default. Psychiatric morbidity and personality traits were assessed by Cornell Medical Index and 16PF personality questionnaire, respectively. Out of 214 patients registered, $176(82.2 \%)$ had psychiatric comorbidity. $150(85.2 \%)$ had anxiety neurosis, and $26(14.8 \%)$ had depression. On personality assessment, $54.1 \%$ were neurotic, $26 \%$ introverts, $15.8 \%$ extroverts, and $4.1 \%$ had other traits. A second study $^{12}$ fallowing 500 patients of pulmonary tuberculosis undergoing DOTS therapy to measure psychological and sociological problems. Among psychological problems pulmonary tuberculosis patients undergoing DOTS therapy showed maximum results in category of sadness due to disease $(76.2 \%)$, followed by feeling emotionally disturbed 
(73.2\%), followed by patients loosing temper while dealing with others $(53.2 \%)$, and in the presence of sleep disturbance (51.2\%). Among sociological problems, patients with pulmonary tuberculosis undergoing DOTS therapy showed maximum results in category of finding difficulty to continue job(41.2\%), followed by preferring stay alone $(39.6 \%)$, followed by not finding cooperation from colleagues at workplace (25.2\%), followed by feeling of isolation by friends and relatives (24.8\%), and loss of job due to disease $(23.6 \%)$.

In our study, category of treatment or duration of treatment was independently associated with psychiatric co-morbidity. The longer the duration, the more prominent are the psychiatric comorbidity. Prolonged duration of illness could cause helplessness, can also lead to financial burden and Patient might develop fearfulness towards tuberculosis leading to more psychiatric co-morbidity. It is comparable with studies by Purohit et $\mathrm{al}^{13}(1978)$, Mathai et $\mathrm{al}^{14}(1981)$, Bhatia et $\mathrm{al}^{15}(2000)$, Panchal et $\mathrm{al}^{8}(2011)$, Ige and Lasebikan et $\mathrm{al}^{16}(2011)$, and it differs from Yadav et $\mathrm{al}^{17}(1980)$, study in which duration of illness was not related to the psychiatric morbidity. In our study, as compared to category I (62.71\%), other categories were significantly and independently at high risk of psychiatric co-morbidity, such as category II (75.47\%) and category IV (85.33\%). It is comparable with studies by Panchal et $\mathrm{al}^{8}$ (2011) and Ige and Lasebikan ${ }^{16}$ (2011).

In our study magnitude of psychiatric comorbidity decreased significantly across the treatment period among Tuberculosis patients at 10-15days (75.42\%) and at 55-60 days (60.37\%). This finding was similar to that reported in a study in Ethiopia by Deribew et $\mathrm{al}^{18}(2013)$.

\section{Conclusion}

In the present study, high proportion of psychiatric co-morbidity was observed among tuberculosis patients. As compared to category I other categories (i.e. II and IV) were significantly and independently at high risk of psychiatric co- morbidity. Magnitude of psychiatric co-morbidity decreased significantly across the treatment period among Tuberculosis patients. Age 31-45 years, males, married and urban had more chance of psychiatric co-morbidity. SES $\mathrm{V}$ has more psychiatric co-morbidity compared to SES III and IV.

Such research has an important role in uncovering the complex nexus between psychosocial, cultural and physical manifestations of Tuberculosis within and across diverse communities.

Developing methods to address psychiatric health issues associated with tuberculosis will lead to innovative approaches to Tuberculosis care and prevention. Innovations might improve disease control but may also challenge or disrupt established control methods. Research should be aimed at understanding the experience of people living with Tuberculosis, their health-seeking behavior, and their strategies for coping with diagnosis, treatment initiation and medication adherence within the context of their living and social situation.

\section{Acknowledgements and disclosures: none Statement of interests: none}

\section{References}

1. Herchline TE; Tuberclosis. Available from http:// emedicine. medscape.com/article/ 230802 overview. Last accessed on 5th May 2015 at $5 \mathrm{pm}$.

2. Central TB Division, Government of India. TB India 2012. Revised National TB Control Programme. Annual Status Report. New Delhi: Central TB Division, Directorate General of Health Services, Ministry of Health and Family Welfare; 2012. Available from: http://tbc india.nic.in /pdfs/TB\%20India\%202012\%20Annual\%20 Report.pdf. Last accessed on 10th May 2015 at $5 \mathrm{pm}$.

3. West away MS, Wolmarans L; Depression and self-esteem: rapid screening for depression in black, low literacy, 
hospitalized TB patients. Social Science and Medicine, 1992; 35: 1311-15.

4. Aghanwa HS, Erhabor GE; Demographic/ socioeconomic factors in mental disorders associated with TB in southwest Nigeria. Journal of Psychosomatic Research, 1998; 45: 35360.

5. Rivinder NB; Depression. Available from http://www.webmd.com/depression/default. htm. Last accessed on 12th May 2015 at 6 pm.

6. P. Vega, A. Sweetland, J. Acha et al., "Psychiatric issues in the management of patients with multidrug-resistant tuberculosis," International Journal of Tuberculosis and Lung Disease, vol. 8, no.6,pp.749-759,2004.

7. G. D. Natani, N. K. Jain, and T. N. Sharma, "Depression in tuberculosis patients: correlation with duration of disease and response to anti-tuberculous chemotherapy," Indian Journal of Tuberculosis, vol.32, no.4, pp.195-198,1985.

8. S.L.Panchal, "Correlation with duration and depression in TB patients in rural Jaipur district," International Journal of Pharma and Bio-Sciences, vol.2,no.2,p. B.263,2011.

9. Lecrubier Y, Sheehan D, Weiller E, Amorim P, Bonora I, Sheehan K, Janavs J, Dunbar G. The Mini International Neuropsychiatric Interview (M.I.N.I.), a short diagnostic interview: Reliability and validity according to the CIDI. European Psychiatry, $1997 ; 12$ : 224-231.

10. Sheehan DV, Lecrubier Y, Harnett Sheehan K, Janavs J, Weiller E, Bonora LI, Keskiner A, Schinka J, Knapp E, Sheehan MF, Dunbar GC. Reliability and validity of the Mini International Neuropsychiatric Interview (M.I.N.I.) according to the SCIDP. European Psychiatry, 1997 ; 12 : 232-241.

11. A.Bansal, S.Chaudhri, and S.Agnihotri, "Impact of psychiatric morbidity and personality trait on treatment completion and default in patients taking directly observed treatment for tuberculosis," European Respiratory Society, 2010.

12. V. Williams and H. Kaur, "The psychosocial problems of pulmonary tuberculosis patients undergoing DOTS therapy (direct observed treatment short course therapy) in selected areas of jalandhar district, punjab," Journal of Pharmacy and Biological Sciences, vol.1,no.1,pp.44-49,2012.

13. Purohit, D.R., Purohit, S.D. and Dhariwal, M.L. 1978. Incidence of depression in Hospitalized T.B. Patients. Ind. J. Tub. 25(3): 147-150.

14. Mathai, J.P., Ravindran, P., Joshi, P. and Sundaram, P. 1981. Psychiatric morbidity in pulmonary Tuberculosis: A clinical study. Ind. J. Psychiat. 23(1): 66-68.

15. Bhatia, M.S., Dubey, K.K., Bhasin, S.K. and Sindhi, N. 2000. Psychiatric morbidity in Tuberculosis patients. Ind. Med. Gezette. 134(1): 5-6.

16. Ige, O.M. and Lasebikan, V.O. 2011. Prevalence of depression in tuberculosis patients in comparison with nontuberculosis family contacts visiting the DOTS clinic in a Nigerian tertiary care hospital and its correlation with disease pattern. Ment. Health Fam. Med. 8(4): 235241.

17. Yadav, B.S., Jain, S.C., Sharma, G., Mehrotra, M.L. and Kumar, A. 1980. Psychiatric morbidity in pulmonary tuberculosis. Ind. J. Tub. 27(4): 147-151.

18. Deribew A, Deribe K, Reda AA, Tesfaye M, Hailmichael Y, Maja $T$, et al. Change in quality of life: a follow up study among patients with HIV infection with and without TB in Ethiopia. BMC public health 2013; 13: 408. 